\title{
THE ROLE OF MAGNESIUM IN INCREASING OF PHOSPHORUS FERTILIZER EFFICIENCY AND WHEAT YIELD
}

\author{
Ghafoor A. Mam Rasul \\ Akram Othman Esmail \\ Ra' ad Jorj \\ Mekha \\ Univ. of Sulaimani \\ College of Agriculture \\ Univ. of Salahaddin
College of Agriculture \\ Univ. of Salahaddin \\ College of \\ Agriculture \\ Soil and Water Sci. Dept. Soil and Water Sci. Dept \\ Dept \\ Soil and Water Sci.
}

\begin{abstract}
The study was conducted during the growing season 2003 to study the influence of four levels of $\mathrm{P}\left(0,60,100\right.$ and $\left.140 \mathrm{~kg} \mathrm{ha}^{-1}\right)$ and four levels of $\mathrm{Mg}$ $\left(0,40,80\right.$ and $\left.120 \mathrm{~kg} \mathrm{ha}^{-1}\right)$ at two locations (Bakrajow and Kalar) on growth and yield of wheat and phosphorus fertilizer efficiency. The results indicated to the response of wheat to phosphorous fertilizer at Bakrajow location only. While the application of $40 \mathrm{~kg} \mathrm{Mg} \mathrm{ha}{ }^{-1}$ caused significant increase in wheat yield at Bakrajow location only. The highest phosphorus fertilizer efficiency was $34.44 \%$ and $55.24 \%$ at Bakrajow and Kalar respectively while the $\mathrm{Mg}$ fertilizer efficiency was $7.6 \%$ and $22.8 \%$ at Kalar and Bakrajow respectively.
\end{abstract}

\section{INTRODUCTION}

There are many factors influencing phosphorus availability, efficiency and recovery of phosphorus fertilizer by plants like soil $\mathrm{pH}$, texture, type of clay minerals, calcium carbonate content of the soil, organic matter content of the soil and $\mathrm{Mg} / \mathrm{Ca}$ ratio of irrigation water or soil solution in additional to mycorhizal activity (Foth, et al., 2000; Al- Akrawi, 2002). Magnesium plays a positive role in phosphorus availability and recovery of phosphorus by crops in calcareous soil like magnesium concentration in soil solution. Magnesium can alter the formation of calcium phosphate precipitates and apatite formation (Marin and Babcok, 1977). On the other hand Kuo and Milkkelsen (1977) showed that magnesium may interfere with phosphorus adsorption on $\mathrm{CaCO}_{3}$ surface by one of the following mechanisms:

1-Magnesium that alters some of adsorption sites on $\mathrm{CaCO}_{3}$ surface, due to lower affinity of phosphate to $\mathrm{Mg}^{2+}$ in comparing with $\mathrm{Ca}^{2+}$ which causes the decrease in phosphorus adsorption by $\mathrm{CaCO}_{3}$.

2-The extend to which magnesium will affect the availability of phosphorus depends on the mole ratio of $\mathrm{P} / \mathrm{Mg}$, if the ratio is equal or less than $2: 1$ the efficiency of phosphorus will increase due to the reduction in adsorption of phosphorus by $\mathrm{CaCO}_{3}$ which causes increase of available phosphorus in calcareous soil, since the solubility of magnesium orthophosphate slightly higher than the solubility of calcium orthophosphate. Dawood (1982) indicated that the application of three levels $\left(0,120\right.$ and $240 \mathrm{~kg} \mathrm{MgSO}_{4} \cdot 7 \mathrm{H}_{2} \mathrm{O}$ ha $\left.{ }^{-1}\right)$ caused a significant increase in phosphorus uptake by plant. Al-Lami (1999) showed that the increase in adding of $\mathrm{MgSO}_{4} \cdot 7 \mathrm{H}_{2} \mathrm{O}$ from 0 to $80 \mathrm{~kg} \mathrm{ha}^{-1}$ caused a significant increase in available phosphorus in the soil from 0.23 to $0.25 \mathrm{cmol}_{\mathrm{c}} \mathrm{kg}^{-1}$. 
On the other hand the $\mathrm{Mg} / \mathrm{Ca}$ ratio plays an important role in phosphorus availability. Madrid, et al.(1977) showed that the increase in utilization efficiency

Received 10/5/2009 accepted 20/9/2010

of phosphorus fertilizer by rye grass as the ratio of $\mathrm{Mg} / \mathrm{Ca}$ increased by the incorporation of $\mathrm{MgSO}_{4} .7 \mathrm{H}_{2} \mathrm{O}$ with dicalocium phosphate and octacalcium phosphate. Al-Khatteb et al.(1986) found the formation of higher amount of dimagnesium phosphate and trimagnesium phosphate, if the ratio of $\mathrm{Mg} / \mathrm{Ca}$ higher than 1.5 which caused the increase in phosphorus availability. Al-Kaysi and Saleem (1990) applied different ratios (0/0, 0/200, 50/150, 100/100, $150 / 50,200 / 0 \mathrm{meq} \mathrm{L}^{-1}$ ) $0 \mathrm{Mg} / \mathrm{Ca}$ they indicated that the increase in the ratio of applied $\mathrm{Mg} / \mathrm{Ca}$ caused an increase in phosphorus availability for plants. Esmail (1992); Dohuki (1997); Abbod (1998) and Esmail, et al.(1999) indicated that the increase in $\mathrm{Mg} / \mathrm{Ca}$ to 1.5 in soil solution and irrigation water caused a significant increase in available phosphorus in the soil and its recovery by plant. Al-Akrawi (2002) studied the influence of four levels $(0,40,80,120 \mathrm{~kg}$ $\mathrm{Mg} \mathrm{ha}^{-1}$ ) of $\mathrm{Mg}$ on the efficiency of phosphorus fertilizer by using three levels of triple superphosphate $\left(0,100,200 \mathrm{~kg} \mathrm{P} \mathrm{ha}^{-1}\right)$ she found that the application of $120 \mathrm{~kg} \mathrm{ha}^{-1}$ of $\mathrm{Mg}$-fertilizer caused the conversion of phosphorus phase to more soluble from (DCPD) in comparing with control treatment (above OCP). For the mentioned reason the purpose of this study includes the role of $\mathrm{Mg}$ fertilizer in P-availability, growth and yield of wheat at two different locations.

\section{MATERIALS AND METHODS}

The experiment was conducted at two different locations ( Bakrajow and Kalar) under rain-fed condition during the winter growing season 2003 to study the influence of four levels of $\mathrm{Mg}$ as $\mathrm{MgSO}_{4} \cdot 7 \mathrm{H}_{2} \mathrm{O}\left(0,40,80,120 \mathrm{~kg} \mathrm{ha}^{-1}\right)$ and four levels of P as TSP $\left(0,60,100\right.$ and $\left.140 \mathrm{~kg} \mathrm{ha}^{-1}\right)$ and their interaction on wheat yield ,availability of phosphorus and the efficiency of phosphorus and magnesium fertilizers using Randomized Complete Block Design (RCBD) with three replicates. $100 \mathrm{~kg} \mathrm{~N} \mathrm{ha}^{-1}$ as urea fertilizer was added at the sowing time. On 20 and 24 November 2003 seeds of wheat variety Acsad were planted at Bakrajow and Kalar respectively. The plants from Kalar location were harvested on 26 may 2004 while at Bakrajow the harvesting was conducted on 1 June 2004. Soil samples were taken from all experimental units at (0 to 30 $\mathrm{cm}$ ) depth before sowing and after harvesting, then air dried thoroughly mixed, ground passed through a $2 \mathrm{~mm}$ sieve, and stored in plastic bottles prior to analysis. Some physical and chemical properties of the soils are given in (table 1). Electrical conductivity (EC) was measured for the soil saturation extract using EC-meter, model (WTW 82362 Weilheim, Germany). pH was measured in a saturated peaste using a $\mathrm{pH}$-meter, model (Microprocessor $\mathrm{pH}$ meter, Hanna pH 211).Organic matter was determined by dichromate oxidation (Walkley and Black method) as described in Jackson (1973). The total calcium carbonate equivalent $\mathrm{CaCO}_{3}$ was determined by a rapid titration method (Rayment and Higginson, 1992).Cation Exchange Capacity (CEC) was 
determined by saturation with $1 M \mathrm{NH}_{4} \mathrm{OAc}$ at $\mathrm{pH}$ 8.1. Soluble $\mathrm{HCO}_{3}{ }^{-}, \mathrm{Cl}^{-}$and $\mathrm{Ca}^{2+}+\mathrm{Mg}^{2+}$ were determined using titration methods (Page et al., 1982). $\mathrm{Na}^{+}$ and $\mathrm{K}^{+}$were determined by using (Flame Photometer). $\mathrm{SO}_{4}{ }^{2-}$ was indirectly determined from combined $\mathrm{Ca}$ and $\mathrm{Mg}$ by titration with $(0.02 M)$ EDTA disodium salt according to Jackson (1958). Available $\mathrm{P}$ was determined by extracting the samples with $0.5 M \mathrm{NaHCO}_{3}$ (Olsen et al., 1954). The particle size was determined according to international pipette method as described by Day (1965).

Table (1): some physical and chemical properties of soil used in field experiments.

\begin{tabular}{|c|c|c|c|}
\hline \multicolumn{2}{|l|}{ Properties } & \multicolumn{2}{|c|}{ Location } \\
\hline \multirow{4}{*}{$\begin{array}{c}\text { Particle Size } \\
\text { Distribution(PSD) } \mathrm{g} \mathrm{kg}^{-1}\end{array}$} & & Bakrajow & Kalar \\
\hline & Sand & 115.4 & 234 \\
\hline & Silt & 523.6 & 572 \\
\hline & Clay & 361 & 196 \\
\hline \multicolumn{2}{|l|}{ Texture Class } & $\mathrm{SiCL}$ & SiL \\
\hline \multicolumn{2}{|l|}{$\mathrm{pH}$} & 7.90 & 7.60 \\
\hline \multicolumn{2}{|l|}{$\mathrm{EC}_{\mathrm{e}} \mathrm{dS} \mathrm{m} \mathrm{m}^{-1}$ at $25^{\circ} \mathrm{C}$} & 0.40 & 2.60 \\
\hline \multirow{7}{*}{ Soluble ions $\mathrm{mmol}_{\mathrm{c}} \mathrm{L}^{-1}$} & $\mathrm{Ca}^{2+}$ & 1.70 & 12.0 \\
\hline & $\mathrm{Mg}^{2+}$ & 0.31 & 4.60 \\
\hline & $\mathrm{Na}^{+}$ & 0.48 & 4.20 \\
\hline & $\mathrm{K}^{+}$ & 0.19 & 6.10 \\
\hline & $\mathrm{HCO}_{3}^{-}$ & 2.95 & 3.20 \\
\hline & $\mathrm{Cl}^{-}$ & 0.21 & 16.10 \\
\hline & $\mathrm{SO}_{4}^{2-}$ & 0.81 & 20.10 \\
\hline \multicolumn{2}{|c|}{$\begin{array}{l}\text { Cation Exchange capacity } \\
\text { cmol }_{\mathrm{c}} \mathrm{kg}^{-1}\end{array}$} & 29.76 & 22.10 \\
\hline \multicolumn{2}{|l|}{ O. M. $\mathrm{g} \mathrm{kg}^{-1}$} & 17.6 & 7.57 \\
\hline \multicolumn{2}{|l|}{ Available P mg kg } & 6.5 & 9 \\
\hline $\begin{array}{c}\mathrm{CaCO}_{3} \text { equivalent } \\
\mathrm{g} \mathrm{kg}^{-1}\end{array}$ & Total & 328.00 & 370.3 \\
\hline
\end{tabular}

Plant analysis: The representative harvested wheat shoots were dried at $65^{\circ} \mathrm{C}$ for $72 \mathrm{hr}$ dried plant material were grinded then digested according to Schuffelen and Schouwenburg(1961) using (1:1 conc. $\mathrm{H}_{2} \mathrm{SO}_{4}$ and $\mathrm{H}_{2} \mathrm{O}_{2}$ )mixture to determination the concentration of phosphorus in digested plant samples according to colorimetric method as described by Rowell (1996).

Biological parameters were calculated using the following models:

Relative yield $=$ (yield of control $/$ yield of fertilized treatment) $\mathrm{x}$ $100 \ldots . . . . . . . . .(1)$

Response $\%=($ yield fertilized - yield control $) /$ yield fertilized $\mathrm{x}$ $100 \ldots . . . . . . . . .(2)$

FUS $=[\{$ P-uptake $($ fertilized $)-$ P-uptake $($ control $)\} /$ P-added $] \quad \mathrm{X}$ $100 \ldots . . . . . . . .(3)$ 
According to Westerman, 1990 and Tisdale, et al., 1997.

\section{RESULTS AND DISCUSSION}

Influence of different levels of $\mathrm{Mg}$ and $\mathrm{P}$ fertilizer and their interaction on grain weight: Table (2) shows the significant effect of $\mathrm{Mg}, \mathrm{P}$ and their interaction on grain yield at Bakrajow location, the highest values 5142.6, 5113.3 and $5605.2 \mathrm{~kg} \mathrm{ha}^{-1}$ were recorded from treatments, $\mathrm{Mg}_{1}, \mathrm{P}_{1}$ and $\mathrm{Mg}_{2} \mathrm{P}_{3}$ respectively. The above results indicated that the combination between $\mathrm{Mg}$ and $\mathrm{P}$ caused the decrease in P-fertilizer requirement for the highest yield.Table (3) indicated that the $\mathrm{Mg}$, P-fertilizer and their interaction were no affected significantly on grain yield this may be due to the high concentration of $\mathrm{Mg}$ in Kalar soil $\left(4.20 \mathrm{mmol}_{\mathrm{c}} \mathrm{kg}^{-1}\right)$ and high 1.2 ratio of $\mathrm{Na} / \mathrm{Ca}$ ratio this may causes the increase in phosphorus availability the similar results were obtained by Esmail (1992).

Table (2): Influence of different rates of $\mathrm{Mg}, \mathrm{P}$ and their interaction on wheat grain yield $\left(\mathrm{kg} \mathrm{ha}^{-1}\right)$ at Bakrajow location.

\begin{tabular}{|c|c|c|c|c|c|c|}
\hline $\mathrm{Pg}$ & $\mathrm{P}_{0}$ & $\mathrm{P}_{1}$ & $\mathrm{P}_{2}$ & $\mathrm{P}_{3}$ & mean & $\begin{array}{c}\text { \%Fertilizer } \\
\text { efficiency }\end{array}$ \\
\hline $\mathrm{Mg}_{0}$ & 4690.0 & 4680.0 & 5085.2 & 5005.2 & 4865.1 & 0 \\
\hline $\mathrm{Mg}_{1}$ & 5205.2 & 5545.2 & 4930.0 & 4890.0 & 5142.6 & 22.8 \\
\hline $\mathrm{Mg}_{2}$ & 4650.0 & 4980.0 & 4805.2 & 5605.2 & 5010.1 & 12.0 \\
\hline $\mathrm{Mg}_{3}$ & 4440.0 & 5248.0 & 4920.0 & 5120.0 & 4932.0 & 5.6 \\
\hline mean & 4746.0 & 5113.3 & 4935.2 & 4985.2 & & \\
\cline { 1 - 4 } $\begin{array}{c}\text { \%Fertilizer } \\
\text { efficiency }\end{array}$ & & 30.92 & 15.88 & 34.44 & & \\
\hline
\end{tabular}

$\operatorname{RLSD}_{0.05} \mathrm{P}=101.2 \quad \mathrm{RLSD}_{0.05} \mathrm{Mg}=101.2 \quad \mathrm{RLSD}_{0.05} \mathrm{Mg}$ x P $=212.8$

Table (3): Influence of different rates of $\mathrm{Mg}, \mathrm{P}$ and their interaction on wheat grain yield $\left(\mathrm{kg} \mathrm{ha}^{-1}\right)$ at Kalar location.

\begin{tabular}{|c|c|c|c|c|c|c|}
\hline $\mathrm{Pg}$ & $\mathrm{P}_{0}$ & $\mathrm{P}_{1}$ & $\mathrm{P}_{2}$ & $\mathrm{P}_{3}$ & mean & $\begin{array}{c}\text { \%Fertilizer } \\
\text { efficiency }\end{array}$ \\
\hline $\mathrm{Mg}_{0}$ & 2351.2 & 3117.2 & 3150.0 & 2592.0 & 2802.6 & 0 \\
\hline $\mathrm{Mg}_{1}$ & 2738.4 & 2655.2 & 2680.0 & 2565.2 & 2659.7 & 0 \\
\hline $\mathrm{Mg}_{2}$ & 2600.0 & 2798.4 & 2870 & 2558.4 & 2706.7 & 0 \\
\hline $\mathrm{Mg}_{3}$ & 2668.4 & 2983.2 & 3088.4 & 2675.2 & 2853.8 & 7.6 \\
\hline mean & 2589.5 & 2888.5 & 2947.1 & 2597.7 & \multicolumn{2}{|}{} \\
\cline { 1 - 4 } $\begin{array}{c}\text { \%Fertilizer } \\
\text { efficiency }\end{array}$ & & 45.72 & 55.24 & 1.24 & & \\
\cline { 1 - 3 }
\end{tabular}

RLSD $_{0.05} \mathrm{P}=$ n.s. $\quad$ RLSD $_{0.05} \mathrm{Mg}=$ n. s. $\quad \mathrm{RLSD}_{0.05} \mathrm{Mg}$ x $\mathrm{P}=273.2$

Influence of different rates of $\mathrm{Mg}, \mathbf{P}$ fertilizer and their interaction on $\mathbf{P}$ concentration and $P$ uptake of wheat grain at Bakrajow location ( $\left.\mathrm{kg} \mathrm{ha}^{-1}\right)$ :

Table (4 and 5) indicated to significant effect of $\mathrm{Mg}, \mathrm{P}$ rates and their interaction on phosphorus concentration and uptake at level of significant 0.05. 
The highest values of phosphorus concentration $\left(4.65,4.18\right.$ and $5.00 \mathrm{mg} \mathrm{g}^{-1}$ ) were recorded from $\mathrm{Mg}_{3}, \mathrm{P} 1$ and $\mathrm{Mg}_{3} \mathrm{P}_{3}$ respectively, but the highest wheat yield were not recorded from the above treatments as mentioned before (table 2) since the concentration of nutrients are not responsible for limiting the yield but the nutrient balance index is responsible for limiting the yield or increasing in nutrient balance in plant causes increase in yield as mentioned by Darwesh (2007). He indicated to the highest wheat yield in treatment or treatment combination which has the highest nutrient balance (low nutrient balance index NBI). On the other hand the highest P uptakes (2256.43, 2164.78 and 2717.20 $\mathrm{kg} \mathrm{ha}{ }^{-1}$ ) were recorded from $\mathrm{Mg}_{3}, \mathrm{P}_{1}$, and $\mathrm{Mg}_{1} \mathrm{P}_{1}$ treatments, this means the increase in $\mathrm{P}$ uptake to a certain level caused increase in wheat yield due to the role of phosphorus in seed formation and increase in weight of 1000 seeds (Salih,2008).

Table (4): Influence of different rates of $\mathrm{Mg}, \mathrm{P}$ and their interaction on phosphorus concentration $\left(\mathrm{mg} \mathrm{g}^{-1}\right)$ at Bakrajow location.

\begin{tabular}{|c|c|c|c|c|c|}
\hline $\mathrm{P}$ & $\mathrm{P}_{0}$ & $\mathrm{P}_{1}$ & $\mathrm{P}_{2}$ & $\mathrm{P}_{3}$ & mean \\
\hline $\mathrm{Mg}_{0}$ & 2.20 & 2.23 & 2.22 & 3.00 & 2.41 \\
\hline $\mathrm{Mg}_{1}$ & 3.21 & 4.87 & 3.31 & 3.50 & 3.72 \\
\hline $\mathrm{Mg}_{2}$ & 3.80 & 4.70 & 4.20 & 3.70 & 3.93 \\
\hline $\mathrm{Mg}_{3}$ & 4.21 & 4.90 & 4.49 & 5.00 & 4.65 \\
\hline mean & 3.36 & 4.18 & 3.56 & 3.80 & \\
\cline { 2 - 7 } $\operatorname{RLSD}_{0.05} \mathrm{P}=0.80$ & $\mathrm{RLSD}_{0.05} \mathrm{Mg}=0.80$ & \multicolumn{5}{|c|}{$\mathrm{RLSD}_{0.05} \mathrm{Mg} \times \mathrm{P}=1.41$}
\end{tabular}

Table (5): Influence of different rates of $\mathrm{Mg}, \mathrm{P}$ and their interaction on phosphorus uptake $\left(\mathrm{kg} \mathrm{ha}^{-1}\right)$ at Bakrajow location.

\begin{tabular}{|c|c|c|c|c|c|}
\hline $\mathrm{P}$ & $\mathrm{P}_{0}$ & $\mathrm{P}_{1}$ & $\mathrm{P}_{2}$ & $\mathrm{P}_{3}$ & mean \\
\hline $\mathrm{Mg}_{0}$ & 938.00 & 1029.60 & 1102.20 & 1525.56 & 1148.84 \\
\hline $\mathrm{Mg}_{1}$ & 533.20 & 2717.20 & 1724.60 & 1725.52 & 1675.13 \\
\hline $\mathrm{Mg}_{2}$ & 1767.00 & 2340.80 & 2249.20 & 1441.56 & 1949.64 \\
\hline $\mathrm{Mg}_{3}$ & 1864.80 & 2571.52 & 2129.40 & 2460.00 & 2256.43 \\
\hline mean & 1275.75 & 2164.78 & 1801.35 & 1788.16 & \\
\hline
\end{tabular}

$\mathrm{RLSD}_{0.05} \mathrm{P}=437.2 \quad \mathrm{RLSD}_{0.05} \mathrm{Mg}=437.2 \quad \mathrm{RLSD}_{0.05} \mathrm{Mg}$ x P $=750$

Influence of different rates of $\mathbf{M g}, \mathbf{P}$ fertilizer and their interaction on $\mathbf{P}$ concentration and $P$ uptake of wheat grain at Kalar location ( $k g$ ha 1):Table (6 and 7) shows the increase in rates of $\mathrm{Mg}$ and $\mathrm{P}$ to a certain level caused a significant increase in phosphorus content of grains at level of significant 0.05 , the highest values $\left(4.50,4.20\right.$ and $\left.4.80 \mathrm{mg} \mathrm{g}^{-1}\right)$ were recorded from the treatments $\mathrm{Mg}_{3}, \mathrm{P}_{2}$ and $\mathrm{Mg}_{3} \mathrm{P}_{3}$, but the highest yield were not recorded from the mentioned treatments this may be due to role of nutrient balance in limiting wheat yield instate of nutrient concentration and uptake. On the other hand the highest $\mathrm{P}$ uptakes (1199.38, 1241.05 and $1480.52 \mathrm{~kg} \mathrm{ha}^{-1}$ ) were obtained from treatments $\mathrm{Mg}_{3}, \mathrm{P}_{2}$ and $\mathrm{Mg}_{0} \mathrm{P}_{2}$ respectively. It is clear that the 
yield of wheat at Bakrajow location is twice to its yield at Kalar location this may be due to the following reasons:

1-The amount of rainfall was 320 and $570 \mathrm{~mm} \mathrm{year}^{-1}$ at Kalar and Bakrajow respectively.

2-The chemical composition and EC of the soil solutions were differ (table 1). The similar results were recorded by Esmail and Darwesh (2007).

3-The soil organic matter content and CEC of Bakrajow soil were higher than their values in Kalar soil while the calcium carbonate content of the Bakrajow soil was lower than its content in Kalar soil(table,1). Which caused the increase in wheat yield at Bakrajow location in comparing with Kalar location .These results agree with those recorded by Salih (2008). He indicated to the influence of soil chemical and physical properties on wheat yield.

Table (6):Influence of different rates of $\mathrm{Mg}, \mathrm{P}$ and their interaction on phosphorus concentration $\left(\mathrm{mg} \mathrm{g}^{-1}\right)$ at Kalar location.

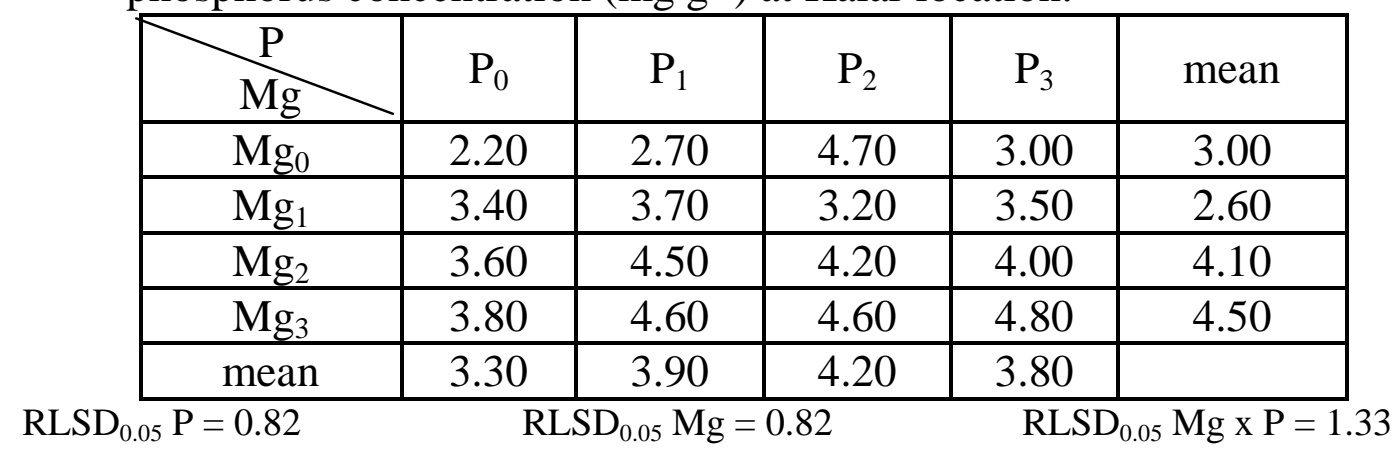

Table (7):Influence of different rates of $\mathrm{Mg}, \mathrm{P}$ and their interaction on phosphorus uptake $\left(\mathrm{kg} \mathrm{ha}^{-1}\right)$ at Kalar locations.

\begin{tabular}{|c|c|c|c|c|c|}
\hline $\mathrm{P}$ & $\mathrm{P}_{0}$ & $\mathrm{P}_{1}$ & $\mathrm{P}_{2}$ & $\mathrm{P}_{3}$ & mean \\
\hline $\mathrm{Mg}_{0}$ & 517.28 & 838.40 & 1480.52 & 777.60 & 903.45 \\
\hline $\mathrm{Mg}_{1}$ & 931.04 & 982.44 & 857.60 & 897.84 & 917.23 \\
\hline $\mathrm{Mg}_{2}$ & 936.00 & 1259.28 & 1205.40 & 1023.36 & 1106.01 \\
\hline $\mathrm{Mg}_{3}$ & 720.48 & 1372.28 & 1420.68 & 1284.08 & 1199.38 \\
\hline mean & 776.20 & 1113.10 & 1241.05 & 995.72 & \\
\hline$R^{2} \mathrm{RLSD}_{0.05} \mathrm{Mg}=205$ & $\mathrm{RLSD}_{0.05} \mathrm{Mg} \times \mathrm{P}=372.6$
\end{tabular}

دور المغنيسيوم في زيادة كفاءة الأسمدة الفوسفاتية و حاصل الحنطة

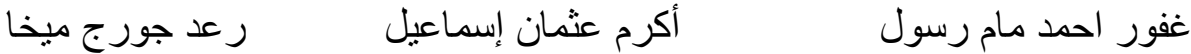

جامعة السليمانية / كلية الزر اعة جامعة صلاح الدين / كلية الزر اعة جامعة صلاح الدين / كلية

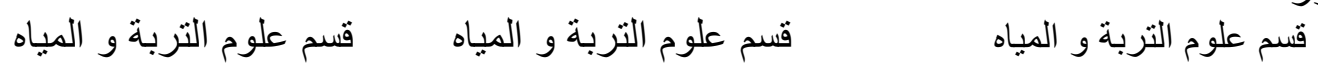

الخلاصة

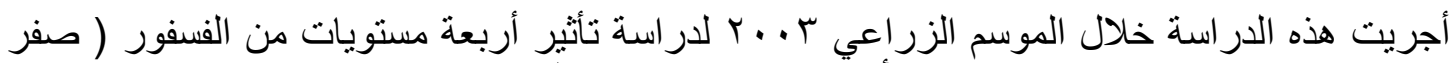

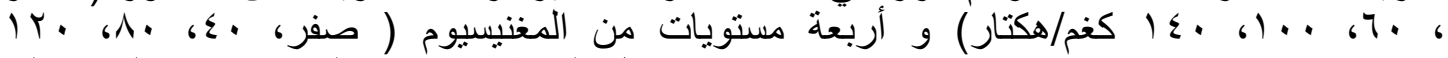

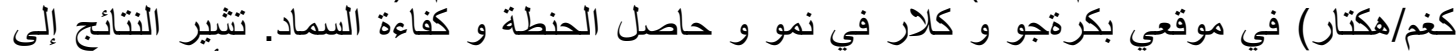

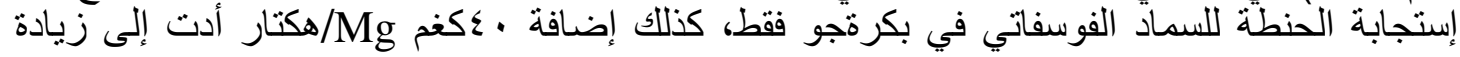




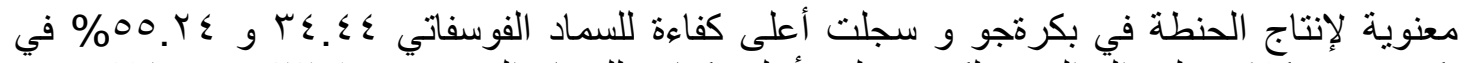

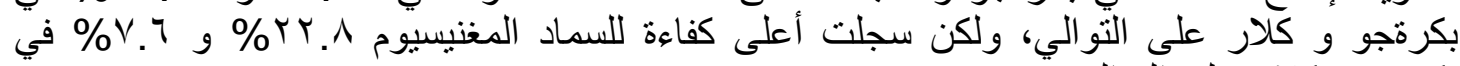
بكرةجو وكلار على التو الي.

\section{REFERENCES}

Abbood, H. Y. (1998) Effect of Salinity and Mg/Ca Ratio of Irrigation Water on Some Soil Characteristic and Availability of Some Nutrient Elements. Ph D Dissertation. College of Agri. Baghdad Univ. Iraq. (In Arabic).

Al-Khatteb, I, K., M. J. Raihan and S. R. Asker (1986) Phase equilibria and kinetics of orthrophosphate in some Iraqi soils, Soil Sci. 141: 31-37.

Al- Kaysi, S. C., and H. B. Saleem (1990). Influence of calcium and magnesium concentration in soil solution on phosphorus availability and transformation in soil. Iraqi J. of Agri. Sci. 21: 164-179.(in Arabic)

Al- Lami, A. S. J.(1999). Evaluation of Magnesium Supplying Power in Plastic Houses Soils. Ph D Dissertation College of Agri. Baghdad Univ.

Al-Akrawi, H. S.Y.(2002). Interaction Effect of Phosphorus and Magnesium on Availability of Phosphorus, Growth and Yield of Zea mayes L. In a Calcareous Soil. M Sc Thesis. Univ. of Salahadden. College of Agri.

Darwesh, D. A.(2007). Role of Supplemental Irrigation and Fertilizer Treatments on Yield and Nutrients Balance in Wheat by Using Modified DRIS. Ph D Thesis Univ. of Salahadden. Soil and Water Dept.

Day, P. R. (1965). Particle Fractionation and Particle-size Analysis. In Blacks, C. A. Methods of Soil Analysis-Part 1 Agronomy 9. American Society Agronomy Inc. Madison, WI. PP.545-567.

Dohuki, M. S. S. M.( 1997). Evaluation of Some Wells and Spring Water in Dohuk Governorate for Irrigation and Drinking Purpose. M Sc. Dissertation. Coll. of Sci. Salahadden Univ.

Dowood, M. A. (1982). Magnesium and Phosphorus Studies In Dohuk and AlHawler Soil and Its Relation to Grass Tetany. M Sc. Dissertation. College. Of Agri. Univ. of Mosul.

Esmail, A. O. (1992). Effect of Ion Composition and Ion Pair in Irrigation Water on Soil and Plant. Ph D. Thesis. Coll. of Agri. Baghdad Univ. (in Arabic).

Esmail, A. O. Kh. M. Kawa and M. F. Yadgar (1999). Effect of Mg/Ca ratio in irrigation water on the yield and quality of chickpea. Iraqi J. Agri. Sci. Zanco. 11: 1- 8 (in Arabic).

Esmail, A. O., and D. A. Darwesh (2007). Role of supplemental irrigation and fertilizer treatment on nutrients balance in wheat by using modified DRIS. J. Dohuk. Univ. 10 (1) 30-38.

Foth, H. D. and G. E. Boyed (2000). Soil Fertility. $2^{\text {nd }}$ edition. Lewis Publishers. Michigan State Univ.

Jackson, M. L. (1958). Soil Chemical Analysis. Prentice Hall. Inc., London.

Jackson, M.L.(1973). Soil Chemical Analysis. Pre Hail of Linda. Pvt. Ltd. Newdelhi.

Kuo, S. and D. S. Mikkelsen (1979). Effect of magnesium phosphate adsorption by calcium carbonate. Soil Sci. 127: 65-69.

Madrid, L., C. Manzuelos, and P. de Arambarri (1977). Effect of application of increasing ratio of magnesium sulfate on the fertilizer value of different calcium phosphate. Phosphorus Agriculture. 71: 1-7. 
Marion, G. M. and K. L. Babbcock (1977). The solubility of carbonates and phosphates in calcareous soil suspension. Soil Sci. Soc. Amer. J. 41: 724 $-728$.

Olsen, S. R., C. V. Cole, F. S. Watatanabe and L. A. Dean (1954). Estimation of Available Phosphorus in Soils by Extraction With Sodium Bicarbonate. USDA Circ 939. US Govt. Print. Office, Washington, DC.

Page, A. L., R. H. Miller and D. R. Kenney, (Ed.) (1982). Methods of Soil Analysis. Part 2. Am. Soc. Agric. Pub. Madison, Wisconsin. U. S. A.

Rayment, G. E. and F. R. Higginson (1992). Australian Laboratory Handbook of Soil and Water Chemical. Inkata Press, Melboume.

Rowell, D. L. (1996). Soil Science. Methods and Application. University of Reading. UK.

Schuffeelen, A. C. A. and J. C. H. Van Schauwenburg (1961).Quick test for soil and plant analysis used by small laboratories. Neth. J. Agric. Aci. 9:2-16.

Tisdale, S. L., W. L. Nelson, J. D. Beaton and J. L. Harlin. 1997. Soil Fertility and Fertilizer. Prentice. Hall of India, New Delhi.

Westerman, R. L. (ed.) (1990). Soil Testing and Plant Analysis. Madison, WI: Soil Sci. Soc. of Am. 